\title{
ANALISIS FAKTOR PENDORONG MASYARAKAT DALAM \\ MEMBANGUN JAMBAN KELUARGA DI DESA SANGKAN GUNUNG KECAMATAN SIDEMEN KABUPATEN KARANGASEM
}

\author{
I Wayan Suarta Asmara, Anysiah Elly Yulianti, I Wayan Sali, \\ Dosen Jurusan Kesehatan Lingkungan Poltekkes Denpasar \\ anysiahyulianti@yahoo.com
}

\begin{abstract}
Sanitation is health efforts to improve the health of the community. Community Based Total Sanitation stipulated by the Decree of the Minister of Health of the Republic of Indonesia Number 852 / Menkes / SK / IX / 2008 on the National Strategy for Community Based Total Sanitation September 9, 2008. The Government has given attention in the field of hygiene and sanitation to define the problem Open Defecation Free $(O D F)$ and improvement of hygienic behavior and healthy in 2009. The purpose of this study was to analyze factors driving people to build family latrines. Methods of research conducted in the form of descriptive analytic with cross sectional design is instantaneous data retrieval field. Then followed by Chi-Square test driving factor in building community family latrines (WC) in the village of Sangkan Gunung district of Sidemen Karangasem. Results of individual factors, especially the level of education with sig $=0.022<a 0,05$ and socio-cultural environment factor sig $=0.014<\alpha$ is a factor driving people to build family latrines, while external factors of formal and informal character not as a motivating factor. Multiple logistic regression test results obtained dominant factor is the level of education and socio-cultural customs of the people do not defecate in fields / gardens as driving people to build family latrines. Applications of this research in the next three years, the village of Sangkan Gunung no longer defecate in any place, according the national target of all Indonesian people already ODF in 2019.
\end{abstract}

Keyword : Family latrines, driving factor

\begin{abstract}
Abstrak : Sanitasi merupakan upaya kesehatan untuk meningkatkan derajat kesehatan masyarakat. Sanitasi Total Berbasis Masyarakat yang ditetapkan dengan Keputusan Menteri Kesehatan Republik Indonesia nomor 852/MENKES/SK/IX/2008 tentang Strategi Nasional Sanitasi Total Berbasis Masyarakat tanggal 9 September 2008. Pemerintah telah memberikan perhatian di bidang hygiene dan sanitasi dengan menetapkan masalah Open Defecation Free (ODF) dan peningkatan perilaku hidup bersih dan sehat pada tahun 2009. Adapun tujuan penelitian ini adalah untuk menganalisis faktor pendorong masyarakat dalam membangun jamban keluarga Metode penelitian dilakukan dalam bentuk deskriptif analitik dengan desain cross sectional yaitu pengambilan data sesaat dilapangan. Proses kemudian dilanjutkan dengan uji Chi-Square faktor pendorong masyarakat dalam membangun jamban keluarga (WC) di Desa Sangkan Gunung Kecamatan Sidemen Kabupaten Karangasem. Hasil faktor individu khususnya tingkat pendidikan dengan sig= 0,022 $<\alpha 0,05$ dan fakor lingkungan sosial budaya sig $=0,014<\alpha$ merupakan faktor pendorong masyarakat untuk membangun jamban keluaga, sedangkan faktor eksternal dari tokoh formal dan informal bukan sebagai faktor pendorong. Hasil uji regresi logistik berganda didapat faktor yang dominan adalah tingkat pendidikan dan sosial budaya kebiasaan masyarakat tidak membuang kotoran di tegalan/kebun sebagai pendorong masyarakat membangun jamban keluarga. Aplikasi penelitian ini dalam tiga tahun ke depan, masyarakat Desa Sangkan Gunung tidak ada lagi yang membuang kotoran di sembarang tempat, sesuai target nasional seluruh masyarakat Indonesia sudah $O D F$ pada tahun 2019.
\end{abstract}

Kata kunci: Jamban Keluarga, Faktor pendorong 



\section{Pendahuluan}

Sanitasi total Berbasis

Masyarakat (STBM) sesuai dengan keputusan Menteri Kesehatan RI nomor 852/ MENKES/SK/IX/2008 tertanggal 9 September 2008 tentang strategi nasional STBM untuk mempercepat akses pelayanan sanitasi di masyarakat. STBM dipertegas lagi dengan Peraturan Menteri Kesehatan nomor 3 tahun 2014 tertanggal 24 Maret 2014. ${ }^{1}$ Untuk mencapai MDGs 2015 dari sektor sanitasi $62,37 \%$ penduduk dapat menikmati pelayanan sanitasi dan kondisi Stop Buang Air Besar Sembarangan, sedangkan untuk air minum $68,87 \%$ penduduk mendapatkan akses air minum. ${ }^{2}$

Hasil survei pada saat memberikan penyuluhan dalam kemah kerja sosial mahasiswa di Kecamatan Sidemen Desa Sangkan Gunung jumlah penduduk 7.737 jiwa dengan jumlah KK 2.031. Kepala Keluarga yang memiliki Jamban Keluarga sebanyak 805 KK, yang menggunakan jamban sebanyak 949 KK yang artinya KK yang menumpang membuang air besar sebanyak 144 KK. Masyarakat Desa Sangkan Gunung yang belum memiliki jamban keluarga sebanyak 1.226 KK dengan prosentase $60 \%$. Seluruh kabupaten/kota di Propinsi Bali telah melaksanakan program STBM. $^{3}$ Sarana pembuangan tinja adalah tempat/ bangunan/ alat untuk membuang tinja dengan tujuan mengurangi atau meniadakan dampak negatif dari tinja.
Menurut Sumantri (2010), pengelolaan tinja (excreta) dapat dilakukan pada on-site, off-site, atau community on-site. Pengolahan tinja secara on-site, tinja ditampung pada penampungan tinja pada jamban yang berada di sekitar rumah. Pengolahan tinja secara off-site tinja dari jamban dialirkan ke tempat pengolahan untuk pengolahan lebih lanjut. Adapun pengelolaan tinja secara community on-site, pengelolaan tinja dilakukan pada sekelompok komunitas secara kolektif. $^{3}$

Pengetahuan adalah merupakan hasil "Tahu" dan ini terjadi setelah orang melakukan penginderaan terhadap suatu objek tertentu yang mana penginderaan ini terjadi melalui panca indera manusia yakni indera penglihatan, pendengaran, penciuman, rasa dan raba yang sebagian besar pengetahuan manusia diperoleh melalui mata dan telinga. ${ }^{4}$ Menurut Purwanto, sikap adalah pandangan atau perasaan yang disertai kecenderungan untuk bertindak sesuai dengan objek. $^{5}$

Penelitian ini bertujuan untuk menganalisis faktor pendorong masyarakat dalam membangun jamban keluarga dan menganalisis faktor manakah yang merupakan faktor dominan pendorong masyarakat dalam membangun jamban keluarga di Desa Sangkan Gunung Kecamatan Sidemen Kabupaten Karangasem Tahun 2015. 
Metode

Penelitian mengambil lokasi di Desa Sangkan Gunung Kecamatan Sidemen Kabupaten Karangasem Provinsi Bali. Jenis penelitian yang digunakan adalah penelitian observasional menggunakan design cross sectional yaitu variabel sebab atau risiko (independent variable) dan akibat atau kasus (dependent variable) yang terjadi pada obyek penelitian diukur atau dikumpulkan secara simultan dalam waktu yang bersamaan. ${ }^{5}$ Instrumen pengumpulan data yang digunakan adalah kuesioner. Populasi pada penelitian ini adalah seluruh jumlah Kepala Keluarga sebanyak 2031 KK. Penentuan sampel dilakukan dengan metode simple random sampling, dengan rumus penarikan sampel sederhana dari Lemeshow. ${ }^{6}$ Untuk memperoleh sampel yang representatif, pengambilan sampel dari setiap wilayah ditentukan secara seimbang atau sebanding (proporsional) dengan banyaknya jumlah KK di masing-masing wilayah. ${ }^{7}$ Adapun jumlah sampel di masing-masing dusun : Dusun Ipah 17 KK, Dusun Mijil 15KK, Dusun Sanggem 16 KK, Dusun Sangkan Gunung 19 KK, Dusun Semseman 15 KK, Dusun Pakel 12 KK, Dusun Luah 14 KK, Dusun Ogang 12 KK, Dusun Dukuh 10 KK. Karakteristik responden adalah kepala keluarga Bapak/Ibu atau anak yang telah berumur di atas 18 tahun dan bersedia diwawancarai. Jika KK tidak kita temukan pada saat survei karena pindah rumah kita pakai KK yang terdekat.

Analisis data dilakukan dengan cara deskriptif dan analitik. Secara deskriptif dengan menggunakan tabulasi frekuensi seperti dan tabulasi silang selanjutnya secara analitik dengan uji Chi-Square yaitu untuk mengetahui hubungan masing-masing variabel independent dengan variabel dependent. Untuk mengetahui pengaruh variabel terikat dan variabel bebas secara multivariat dan serentak menggunakan uji regresi logistik.

\section{Hasil Dan Pembahasan}

Desa Sangkan Gunung mewilayah sembilan banjar/ dusun dengan jumlah penduduk 7737 jiwa yang terdiri dari 3940 jiwa laki-laki dan 3797 jiwa perempuan dengan 2031 Kepala Keluarga (KK).

Karakteristik responden menurut tingkat pendidkan dibedakan menjadi lima yaitu tidak sekolah, SD, SMP, SLTA dan perguruan tinggi. Adapun hasil tabulasi silang antara tingkat pendidikan dengan dorongan masyarakat membangun jamban keluarga, masyarakat yang membangun jamban keluarga berdasarkan tingkat pendidikan yang terbanyak adalah SLTA sebanyak 70 orang $(53,85 \%)$ dan terendah adalah tidak sekolah sebanyak 2 orang $(1,54 \%)$ dalam pembangunan jamban keluarga.

Hasil tabulasi silang antara tingkat pengetahuan dengan dorongan masyarakat membangun jamban keluarga menunjukkan bahwa 
masyarakat yang membangun jamban keluarga berdasarkan pengetahuan yang terbanyak berpengetahuan baik sebanyak $93(71,5 \%)$, berpengetahuan cukup sebanyak 17 orang $(13,1 \%)$ dan berpengetahuan kurang sebanyak 20 orang $(15,4 \%)$. Faktor lingkungan terdiri dari sosial budaya/ kebiasaan dan sosial ekonomi. Karakteristik responden berdasarkan sosial budaya adalah kebiasaan responden membuang air besar dan tidak malu di sembarang tempat (tegalan/ kebun sungai). Dari hasil tabulasi silang menunjukkan masyarakat yang membuang kotoran di jamban berdasarkan sosial budaya sebesar 121 orang $(93,08 \%)$, sedangkan yang tidak membuang kotoran di jamban sebanyak 9 orang (6,92\%). Sosial ekonomi responden adalah rata-rata penghasilan/ gaji yang didapatkan oleh responden setiap bulan, dapat diketahui bahwa sebagian besar masyarakat memiliki penghasilan 1 - 2 juta sebanyak 85 orang $(65,38 \%), 2-3$ juta sebanyak $43(33,08 \%)$ dan yang terendah adalah > 3 juta sebanyak 2 orang (1,54\%). Faktor eksternal yang terdiri dari tokoh formal adalah tokoh masyarakat yang secara kelembagaan berada pada struktur pemerintahan antara lain kepala desa/dusun, petugas kesehatan yang mewilayahi desa tersebut menunjukkan masyarakat yang membangun jamban keluarga berdasarkan dorongan oleh tokoh formal terbanyak adalah dorongan bukan dari tokoh formal sebanyak 86 orang $(66,16 \%)$ dan terkecil adalah dorongan dari kepala desa sebanyak 7 orang $(5,38 \%)$. Karakteristik masyarakat membangun jamban berdasarkan tokoh informal menunjukkan masyarakat yang membangun jamban keluarga berdasarkan dorongan oleh tokoh informal terbanyak adalah bukan dari tokoh informal sebanyak 79 (60,77\%), tokoh informal dari bendesa Adat dengan perangkatnya sebanyak 49 orang $(37,69 \%)$ artinya dorongan/ motivasinya cukup baik, sedangkan terkecil adalah dorongan dari kelompok tani sebesar 2 orang $(1,54 \%)$. Selain faktor tersebut, rasa malu dan atas kemauan sediri merupakan faktor pendorong atau motivasi masyarakat membangun jamban keluarga. Dorongan lainnya masyarakat untuk membangun jamban menunjukkan bahwa masyarakat yang membangun jamban keluarga terbanyak karena kemauan sendiri sebanyak 79 orang $(60,77 \%)$, dan malu sama tetangga sebanyak 51 orang $(39,23 \%)$. Dorongan membangun jamban berdasarkan tingkat pendidikan diketahui bahwa masyarakat yang berpendidikan SLTA $(16,2 \%)$ maupun SMP $(15,4 \%)$ memiliki dorongan membangun jamban karena malu sama tetangga sedangkan masyarakat yang berpendidikan SLTA $(53,8 \%)$ maupun SMP (14,6\%) karena kemauan sendiri untuk membangun jamban keluarga. Berdasarkan hasil uji Chi-Square dapat diketahui bahwa tingkat signifikansi tingkat pendidikan 0,011. Nilai signifikansi tersebut $<$ taraf nyata 
$(\alpha=0,05)$ yang artinya ada hubungan antara tingkat pendidikan masyarakat dengan dorongan membangun jamban keluarga (WC).

Dorongan membangun jamban berdasarkan tingkat pengetahuan diketahui bahwa masyarakat yang berpengetahuan kurang $(10,0 \%)$ maupun yang berpengetahuan baik $(24,6 \%)$ memiliki dorongan membangun jamban karena malu sama tetangga, sedangkan sebagian lainnya masyarakat yang berpengetahuan baik $(46,9 \%)$ memiliki dorongan membangun jamban karena atas kemauan sendiri. Berdasarkan hasil uji ChiSquare diketahui bahwa tingkat signifikansi tingkat pengetahuan 0.037 . Nilai signifikansi tersebut $<$ taraf nyata $(\alpha=0,05)$ yang artinya ada hubungan antara tingkat pengetahuan masyarakat dengan dorongan membuat jamban keluarga. Dorongan masyarakat membangun jamban keluarga berdasarkan sosial budaya menunjukkan bahwa masyarakat yang tidak membuang kotoran di tegalan, mengatakan atau memiliki dorongan membangun jamban keluarga karena malu sama tetangga $(33,8 \%)$, sedangkan sebagian masyarakat lainya $(59,2 \%)$ mengatakan memiliki dorongan membangun jamban keluarga karena kemauan sendiri.

Berdasarkan hasil analisis uji Chi Square diketahui bahwa tingkat signifikansi sosial budaya 0,014. Nilai signifikansi tersebut < taraf nyata $(\alpha=0,05)$ yang artinya ada hubungan antara sosial budaya masyarakat dengan dorongan membangun jamban keluarga.

Distribusi dorongan masyarakat membangun jamban keluarga berdasarkan sosial ekonomi diketahui sebagian besar masyarakat yang berpenghasilan 1-2 juta/ bulan 40 $(30,8 \%)$ memiliki dorongan membangun jamban keluarga karena malu sama tetangga, sedangkan sebagian besar masyarakat yang berpenghasilan 1-2 juta/bulan 45 (34,6\%) memiliki dorongan membangun jamban keluarga karena kemauan sendiri. Berdasarkan hasil analisis uji Chi Square dapat diketahui bahwa tingkat signifikansi dari sosial ekonomi 0,033. Nilai signifikansi tersebut < taraf nyata $(\alpha=0,05)$ yang artinya ada hubungan antara sosial ekonomi masyarakat dengan dorongan/motivasi untuk membangun jamban keluarga.

Dorongan masyarakat membangun jamban keluarga berdasarkan tokoh formal diketahui masyarakat yang tidak mendapat himbauan dari tokoh formal (24,\%) maupun masyarakat yang mendapat himbauan dari petugas kesehatan $(10,8 \%)$ memiliki dorongan membangun jamban keluarga karena malu sama tetangga, sedangkan masyarakat yang tidak mendapat himbauan dari tokoh formal (41,5\%) maupun masyarakat yang mendapat himbauan dari petugas kesehatan $(17,7 \%)$ memiliki dorongan mem-bangun jamban keluarga karena kemuan sendiri. Hasil analisis uji Chi Square dapat diketahui bahwa tingkat signifikansi dari tokoh formal 0,200. 
Nilai signifikansi tersebut $>$ taraf nyata $(\alpha=0,05)$ yang artinya tidak ada hubungan antara tokoh formal dengan dorongan membangun jamban keluarga.

Distribusi dorongan masyarakat membangun jamban keluarga berdasarkan tokoh informal diketahui masyarakat yang tidak mendapat himbauan dari tokoh informal $(23,8 \%)$ maupun masyarakat yang mendapat himbauan dari bendesa adat (13,8\%) memiliki dorongan membangun jamban keluarga karena malu sama tetangga, sedangkan masyarakat yang tidak mendapat himbauan dari tokoh informal $(36,9 \%)$ maupun masyarakat yang mendapat himbauan dari bendesa adat $(23,8 \%)$ memiliki dorongan membangun jamban keluarga, karena kemuan sendiri. Hasil analisis uji Chi Square dapat diketahui bahwa tingkat signifikansi dari tokoh formal 0,199 . Nilai signifikansi tersebut > taraf nyata $(\alpha=0,05)$ yang artinya tidak ada hubungan antara tokoh informal dengan dorongan masyarakat untuk membangun jamban keluarga.

Analisis hubungan faktor individu (tingkat pendidikan, tingkat pengetahuan) dan faktor lingkungan (sosial budaya, sosial ekonomi) serta faktor eksternal (tokoh formal dan tokoh infomal) dapat diketahui dari Tabel 1.

Tabel 1

Analisis Regresi Logistik Multifariat Faktor Individu, Faktor Lingkungan dan Faktor Eksternal Masyarakat Membangun Jamban Keluarga

\begin{tabular}{lccc}
\hline \multicolumn{1}{c}{$\begin{array}{c}\text { Variabel } \\
\text { Independen }\end{array}$} & Sig & $\begin{array}{c}\text { Hubungan dengan } \alpha \\
(0.05)\end{array}$ & Kesimpulan \\
\hline Pendidikan & 0,022 & $<\alpha$ & Faktor dominan \\
Pengetahuan & 0,363 & $>\alpha$ & Tidak dominan \\
Sosial budaya & 0,014 & $<\alpha$ & Faktor dominan \\
Sosial ekonomi & 0,167 & $>\alpha$ & Tidak dominan \\
Constant & 0,001 & & \\
\hline
\end{tabular}

\begin{abstract}
Berdasarkan hasil uji regression binary logistic secara multivariat, faktor individu yang terdiri dari pendidikan dan pengetahuan ternyata memegang peranan penting bagi masyarakat untuk mendorong memmbangun jamban keluarga, yang mana faktor pengetahuan tidak banyak memberikan dorongan masyarakat untuk membangun jamban keluarga. Faktor lingkungan yang terdiri dari sosial budaya dan sosial ekonomi, sosial budaya seperti kebiasaan
\end{abstract}

membuang kotoran di tegalan/ kebun, sungai relatif kecil sebanyak 9 (6,92\%) jadi kebiasaan tidak lagi membuang kotoran di tegalan/kebun menjadikan daya ungkit masayakat untuk membangun jamban keluarga, juga faktor ekonomi cukup berperan juga dalam membangun jamban keluarga walaupun secara statistik mengatakan tidak signifikan namun penghasilan masyarakat 1-2 juta sebanyak 85 orang $(65,38 \%)$ telah dapat membangun jamban apalagi masyarakat yang 
berpenghasilan lebih dari itu. Faktor eksternal yang terdiri dari tokoh formal maupun tokoh informal dari uji awal dengan Chi-Square sudah tidak memiliki hubungan dalam mendorong masyarakat untuk membangun jamban keluarga.

Berdasarkan hasil uji regression binary logistic secara multivariat pada faktor individu dapat diketahui bahwa variabel yang mendorong masyarakat membangun jamban keluarga adalah tingkat pendidikan, variabel yang bukan merupakan pendorong masyarakat membangun jamban keluarga adalah tingkat pengetahuan. Pada faktor lingkungan dapat diketahui bahwa variabel yang mendorong masyarakat membangun jamban keluarga adalah sosial budaya, variabel yang bukan merupakan pendorong masyarakat membangun jamban keluarga adalah sosial ekonomi.

Dorongan/motivasi masyarakat dalam membangun jamban adalah dorongan masyarakat untuk memiliki jamban sendiri agar tidak lagi membuang kotoran di tegalan. Dorongan/motivasi adalah suatu usaha yang dapat menyebabkan seseorang atau kelompok orang tertentu tergerak untuk melakukan sesuatu karena ingin mencapai tujuan yang dikehendakinya atau mendapat kepuasan dengan perbuatannya (Kamus Besar Bahasa Indonesia, 2007). Dorongan atau motivasi terbentuk dari sikap (attitude) dalam menghadapi situasi. Dorongan/ motivasi merupakan kondisi atau energi yang menggerakkan diri seseorang yang terarah atau tertuju untuk mencapai tujuan yang diingankan. ${ }^{8}$

Karakteristik responden menurut tingkat pendidikan dibedakan menjadi 5, yaitu tidak sekolah, SD, SLTP, SLTA dan PT. Dalam penelitian ini dapat diketahui bahwa masyarakat yang tidak sekolah, tamat SD, SLTP dan SLTA maupun yang tamat Perguruan Tinggi mmemiliki motivasi atau dorongan yang besar untuk membangun jamban keluarga. Berdasarkan hasil uji regression binary logistic dapat diketahui bahwa ada hubungan antara tingkat pendidikan masyarakat dengan dorongan membangun jamban keluarga. ${ }^{9}$

Hasil penelitian ini sejalan dengan pendapat Darwin yang menyatakan bahwa semakin tinggi tingkat pendidikan responden, maka proporsi tindakan baik responden akan semakin tinggi. Hal ini sejalan dengan adanya kecenderungan makin tinggi tingkat pendidikan responden, tingkat pengetahuannya juga semakin baik. ${ }^{9}$ Hasil penelitian ini juga sejalan dengan pendapat Monks yang menyatakan bahwa pendidikan secara garis besar merupakan perkembangan kognitif. Hal tersebut menunjukkan bahwa perubahan dalam perkembangan tentang bagaimana memperoleh pengetahuan, menyimpannya, dan menggunakannya sebagai faktor usaha intervensi perilaku, yang dalam hal ini 
adalah dorongan membangun jamban keluarga.

Pengetahuan masyarakat dibedakan menjadi 3, yaitu kurang, cukup dan baik. Dalam penelitian ini dapat diketahui bahwa sebagian besar masyarakat yang berpengetahuan kurang maupun berpengetahuan baik memiliki dorongan membangun jamban keluarga. Berdasarkan hasil uji regression binary logistic dapat diketahui bahwa tidak ada hubungan antara pengetahuan masyarakat dengan dorongan untuk membangun jamban keluarga.

Pada penelitian ini diperoleh informasi sebagian masyarakat mengetahui dampak negatif membuang kotoran di sembarang tempat. Hasil penelitian ini didukung oleh pendapat Benyamin Bloom (1908) membagi perilaku kedalam 3 domain, salah satunya adalah pengetahuan. Pengetahuan atau kognitif merupakan domain yang sangat penting untuk terbentuknya tindakan seseorang. Karena dari pengalaman dan penelitian ternyata perilaku yang didasari pengetahuan akan lebih langgeng daripada perilaku yang tidak didasari oleh pengetahuan. $^{\mathbf{1 0}}$

Green (1980) berpendapat bahwa pengetahuan adalah faktor yang mempermudah terjadinya perubahan perilaku. Sedangkan H.L.Blum menyatakan bahwa status kesehatan atau kejadian penyakit dipengaruhi oleh empat faktor, salah satunya adalah perilaku. Dengan demikian, pengetahuan secara tidak langsung mempengaruhi status kesehatan atau kejadian penyakit. Hasil penelitian ini sesuai dengan teori tersebut.

Sosial budaya, sosial budaya responden adalah kebiasaan responden membuang kotoran dan tidak malu membuang kotoran disembarang tempat. Dalam penelitin ini diperoleh informasi bahwa sebagian besar masyarakat telah membuang kotoran di jamban karena malu dengan tetangga dan atas kemauan sendiri. Berdasarkan hasil uji regression binary logistic dapat diketahui bahwa ada hubungan sosial budaya dengan dorongan masyarakat membangun jamban keluarga. Hal ini didukung oleh pendapat Azwar (2010) yang menyatakan bahwa kebudayaan mempunyai pengaruh yang besar terhadap pembentukan sikap. Tanpa kita sadari, kebudayaan telah menanamkan garis pengarah sikap terhadap berbagai masalah. Kebudayaan telah mewarnai sikap anggota masyarakatnya, karena kebudayaan pulalah yang memberi corak pengalaman individu-individu yang menjadi anggota kelompok masyarakat asuhannya. Hanya kepribadian individu yang telah mapan dan kuatlah yang dapat memudarkan dominasi kebudayaan dalam pembentukan sikap individual. ${ }^{\mathbf{1 1}}$

Dalam Kamus Besar Bahasa Indonesia (2007) sosial dimaknai sebagai segala sesuatu yang berhubungan dengan masyarakat atau 
kemasyarakatan dalam hal ini suka memperhatikan kepentingan umum, sedangkan budaya diartikan sebagai segala hal yang dibuat oleh manusia bedasarkan pikiran dan akal budinya yang mengandung cinta, rasa dan karsa. Sosial budaya masyarakat Desa Sangkan Gunung seperti halnya masyarakat Bali umumnya yang masih berhubungan dengan adat istiadat dalam kegiatan keagaman. Pada setiap kegiatan dilaksanakan secara gotong royong oleh masyarakat. Desa Sangkan Gunung saat ini daerahnya untuk kegiatan pariwisata seperti arung jeram karena di sebelah barat ada sungai Telaga Waja yang airnya cukup jernih dengan aliran yang deras. Setiap hari kawasaan ini banyak dikunjungi oleh para tamu domestik maupun dari manca negara. Sesuai dengan hasil penelitian ternyata kebiasaan masyarakat tidak membuang kotoran di sembarang tempat sebayak 121 (93\%). Hal ini sesuai dengan Permenkes Nomor 3 tahun 2014 tentang STBM dalam pilar yang pertama yaitu stop buang air besar sembarangan.

Sosial ekonomi, sosial ekonomi dalam hal ini adalah upah/gaji yang didapatkan oleh masyarakat setiap bulan. Karakteristik responden berdasarkan sosial ekonomi dibagi menjadi 3 yaitu yang penghasilannya 1-2 juta/bln, 2-3 juta/bulan dan >3 juta /bulan. Pada penelitian ini dapat diketahui bahwa sebagian besar dorongan masyarakat untuk membangun jamban keluarga adalah masyarakat yang berpenghasilan 1-2 juta atas dasar rasa malu sama tetangga dan atas kemauan sendiri. Berdasarkan hasil uji regression binary logistic dapat diketahui bahwa tidak ada hubungan anatara sosial ekonomi dengan dorongan masyarakat untuk membangun jamban keluarga.

Pengertian sosial ekonomi dalam Kamus Besar Bahasa Indonesia (2007), kata sosial berarti segala sesuatu yang berkenaan dengan masyarakat. Sedangkan dalam konsep sosiologi, manusia sering disebut sebagai makhluk sosial yang artinya manusia tidak dapat hidup wajar tanpa adanya bantuan orang lain disekitarnya, sehingga kata sosial sering diartikan sebagai hal-hal yang berkenaan dengan masyarakat

Ekonomi berarti ilmu yang mengenai asas-asas produksi, distribusi dan pemakaian barang-barang serta kekayaan (seperti keuangan, perindustrian, dan perdagangan). Sosial ekonomi masyarakat di Desa Sangkan Gunung relatif merata dari hasil penelitian ternyata masyarakat yang berpenghasilan 1-2 juta per bulan sebanyak $85 \quad(65,38 \%)$ dan yang berpenghasilan 2-3 juta per bulan sebanyak $43 \quad(33,08 \%)$ dapat membangun jamban keluarga, sejalan dengan hukum ekonomi semakin besar pendapatan seseorang akan semakin besar kebutuhan primer maupun skunder dapat terpenuhi.

Sesuai dengan Undang-Undang Nomor 5 tahun 1979 tentang Pemerintahan Desa, menempatkan 
kepala desa sebagai penguasa tunggal di desa. Tokoh formal yang dimaksud dalam penelitian ini adalah masyarakat yang bekerja di pemerintah dari tingkat bawah seperti kepala dusun sebagai pejabat di dusun/banjar sebagai bawahan kepala desa/lurah atau instansi pemerintah lainnya dan digaji oleh pemerintah. Hasil penelitian setelah uji Chi-Square tokoh formal tidak ada hubungannya sebagai faktor prndorong masyarakat dalam membangun jamban keluarga. Hal ini disebabkan karena kurangnya kesempatan untuk bertemu dengan masyarakat secara langsung, umumnya tokoh formal lebih banyak dengan urusan kedinasan. Masyarakat sering berkumpulnya dalam acara upacara adat jadi yang lebih banyak berhadapan dengan masyarakat adalah bendesa adat. Hanya petugas kesehatan yang dari Puskesmas Sidemen dapat memberikan dorongan/motivasi itupun dikatakan oleh responden sebanyak 37 $(28,46 \%)$, kepala desa sebanyak 7 $(5,38)$ responden. Menurut undangundang pemerintahan desa seluruh program pembangunan, khususnya pembangun-an di bidang kesehatan sebagai ujung tombak pelaksanaan program pembangunan di desa adalah kepala desa beserta seluruh jajarannya. Begitu juga program pembengunan dibidang kesehatan adalah para petugas kesehatan bekerja sama kepala desa. Apakah mungkin pada era demokrasi yang serba semuanya transparan saat ini, karena kurang trasparannya perangkat desa untuk berbagai kegiatan atau program pemerintah di tingkat desa membuat tokoh formal kehilangan wibawa, sehingga masyarakat merasa acuh tak acuh terhadap para petugas pemerintah sebagai tokoh formal. Kalau memang hal ini terjadi sebaiknya seluruh perangkat pemerintahan khususnya di desa hendaknya mengembalikan fungsi utama adalah sebagai abdi negara yang dapat memberikan pelayanan sebaikbaiknya kepada masyarakat. Juga para tokoh formal yang ada di Desa Sangkan Gunung khususnya dan pada masyarakat bali umumnya.

Tokoh informal, seperti dikatakan pada Perda Provinsi Bali Nomor 3 tahun 2001 tentang Desa Pakraman dan Perda Nomor 06 tahun 1986 tentang Desa Adat. Desa Pakraman adalah kesatuan masyarakat Hukum Adat di Provinsi Bali, yang mempunyai satu kesatuan tradisi dan tata karama pergaulan hidup masyarakat umat Hindu secara turun temurun dalam ikatan Kahyangan Tiga atau Kahyangan Desa yang mempunyai wilayah tertentu dan harta kekayaan sendiri serta berhak mengurus rumah tangganya sendiri. ${ }^{12}$ Pemimpin desa pakraman disebut Bendesa adat beserta, petajuh atau prajuru adat yang melaksanakan kegiatan dengan berbagai tradisi masyakatnya. Tokoh informal yang dimaksud dalam penelitian ini adalah bendesa adat beserta prajurunya, ketua kelompok organisasi, kelompok tani, seka teruna teruni, PKK dan lainnya yang bergerak di sektor informal. Hasil 
penelitian di desa Sangkan Gunung tokoh informal, bendesa adat sebanyak 49 orang $(37,69 \%)$ responden, dapat memberikan dorongan/ motivasi pada masyarakatnya untuk membangun jamban keluarga. Sedangkan yang mengatakan tidak ada dari tokoh informal sebanyak 79 orang $(60,77 \%)$ responden. Untuk melaksanakan program pemerintah sebaiknya perangkat desa dinas dan desa pakraman saling bersinergi, sehingga program pembangunan khususnya pembangunan di bidang kesehatan seperti membangun fasilitas sanitasi jamban keluarga dapat terlaksana dengan baik. Fasilitas sanitasi khususnya toilet di tempat-tempat wisata yang ada di Bali belum terawat secara profesional seperti di negara maju antara lain Malaysia, Singapura. Namun data yang peneliti dapatkan ternyata faktor pendorong untuk membangun jamban keluarga seperti malu sama tetangga sebanyak 51 $(39,23 \%)$ responden tidak punya jamban keluarga, dan atas kemauan sendiri sebanyak $79 \quad(60,77 \%)$ responden untuk membangun jamban keluarga. Hal ini sejalan program pemerintah dalam Permenkes No. 3 tahun 2014 tentang Sanitasi Total Berbasis Masyarakat (STBM) yaitu pembangunan oleh masyarakat untuk masyarakat.

Pembangunan jamban keluarga/ WC untuk masyrakat Desa Sangkan Gunung yang daerahnya dengan topografi miring dengan ketinggian 500-700 m dari permukaan laut adalah metode on-Site pengolahan setempat berupa sumuran tinja. Ada beberapa persyaratan untuk jamban keluarga yang sehat antara lain tidak mengotori permukaan tanah di sekeliling jamban tersebut, tidak mengotori air permukaan di sekitarnya, tidak mengotori air tanah di sekitarnya, tidak dapat terjangkau oleh serangga terutama lalat dan kecoa, dan binatang lainnya, tidak menimbulkan bau, mudah digunakan dan dipelihara, sederhana disainnya dan murah

Tantangan besar yang dihadapi pemerintah Kabupaten Karangasem terkait permasalahan pembangunan kesehatan sangatlah besar khususnya pada bidang hygiene dan sanitasi. Pemerintah dalam hal ini merubah pendekatan pembangunan sanitasi nasional dari pendekatan sektoral yang selama ini tidak memberi daya ungkit terjadinya perubahan perilaku hygienis dan peningkatan akses sanitasi menjadi pendekatan sanitasi total berasis masyarakat yang menekankan pada lima perubahan perilaku hygienis. Perubahan perilaku dalam STBM dilakukan melalui metoda pemicuan, yang mendorong perubahan perilaku masyarakat sasaran secara kolektif dan mampu membangun sarana sanitasi secara mandiri sesuai kemampuan oleh seluruh komponen masyarakat (PKK, kelompok tani, seka teruna teruni).

Perilaku atau tindakan adalah gerakan atau perbuatan dari tubuh setelah mendapatkan rangsangan ataupun adaptasi dari dalam tubuh maupun luar tubuh atau lingkugan. 
Tindakan seseorang terhadap stimulus tertentu akan banyak ditentukan oleh bagaimana keyakinan dan perasaannya terhadap stimulus tersebut. ${ }^{10}$

Perilaku stop buang air besar sembarangan diikuti dengan pemanfaatan sarana sanitasi yang saniter berupa jamban sehat. Pada penelitian ini kepemilikan jamban keluarga baru mencapai 29\%. Hal ini disebabkan masih kurangnya pengetahuan masyarakat akan manfaat membuang kotoran dijamban dan masih tersedianya lahan cukup luas. Untuk mencapai target nasional pada tahun 2019 kerja keras dari seluruh komponen masyarakat untuk menyediakan/ membangun jamban keluarga untuk masyarakat di Desa Sangkan Gunung. Sangat penting saat ini merubah kebiasaan dan perilaku masyarakat untuk membuang kotoran di jamban. membuang kotoran di jamban. Hal ini juga dapat memanfaatkan peran tokoh formal dan tokoh informal untuk secara bersamasama mengajak masyarakat untuk merubah perilaku dan tidak hentihentinya melakukan partisipasi/ mengajak masyarakatnya untuk membuat jamban karena program STBM di Kabupaten Karangasem begitu juga Desa Sangkan Gunung dilaksanakan sejak tahun 2011.

\section{Simpulan dan Saran}

Simpulan yang dapat diambil dalam penelitian ini adalah faktor individu yang terdiri dari pendidikan merupakan faktor pendorong masayarakat untuk membangun $\begin{array}{lcr}\text { jamban } & \text { keluarga } & \text { sedangkan } \\ \text { pengetahuan } & \text { relatif } & \text { kurang } \\ \text { memberikan } & \text { dorongan } & \text { untuk } \\ \text { membangun } & \text { jamban keluarga } & \text { (WC). }\end{array}$

Namun rasa malu sama tetangga dan kemauan sendiri merupakan faktor yang besar untuk membangun jamban keluarga. Faktor lingkungan yang terdiri dari sosial budaya yang merupakan kebiasaan masyarakat tidak lagi membuang kotoran di tegalan/kebun menjadi faktor dominan untuk mendorong masyarakat membangun jamban keluarga (WC), sedangkan sosial ekonomi tidak banyak memberikan daya ungkit sebagai pendorong masyarakat untuk membangun jamban keluarga (WC). Faktor eksternal yang terdiri dari tokoh formal dan tokoh informal, faktor ini tidak banyak memberikan dorongan masyarakat untuk membangun jamban keluarga (WC). Kepala Desa dan Bendesa Adat sebagai tokoh formal dan informal, hendaknya secara bersama-sama lebih banyak melibatkan masyarakat untuk melaksanakan setiap program pembangaunan khususnya dibidang kesehatan. Petugas kesehatan sebaiknya secara bersinergi dengan Bendesa Adat, Seka Teruna teruni untuk meningkatkan perubahan perilaku masyarakat agar membuang kotoran di jamban keluarga (WC).

\section{Daftar Pustaka}

1. Keputusan Menteri Kesehatan RI no: 852/MENKES/SK/IX/ 2008 tentang Strategi Nasional Sanitasi Total Berbasis Masyarakat

2. Buku Saku MDGs, 2011 
3. Profil Desa Sangkan Gunung Tahun 2013

4. Sumantri A, (2012) Kesehatan Lingkungan, Kencana Prenada Media group, Jakarta

5. Notoatmodjo, Soekidjo, (2007), Promosi Kesehatan dan Ilmu Prilaku, Rineka Cipta, Jakarta.

6. Notoatmodjo, Soekidjo, (2010), Metodologi Penelitian Kesehatan, Edisi Revisi, Cetakan Pertama, Rineka Cipta, Jakarta.

7. Arikunto, Suharsimi, (2010), Prosedur Penelitian suatu Pendekatan Praktik, Rineka Cipta, Jakarta

8. Prabu Mangkunegara, A.A. Anwar, (2009), Perencanaan dan Pengembangan Sumber Daya Manusia, Refika Aditama, Bandung,

9. Lumbantoruan, Efelina, (2007), Pengaruh Karakteristik Individu terhadap Tindakan Pemilik Anjing dalam Pencegahan Penyakit Rabies di Deasa Namoriam Kecamatan Pancur Batu Kabupaten Deli Serdang Tahun 2007, Skripsi, USU, Medan

10. Notoatmodjo, Soekidjo, (2003), Pendidikan dan Perilaku Kesehatan, Rineka Cipta, Jakarta

11. Azwar, S, 2010, Sikap Manusia, Teori dan Pengukurannya, Edisi ke 2,Pustaka Pelajar, Yogyakarta

12. Parimartha, (2013), Desa Adat dan Desa Dinas di Bali, Udayana University press, Denpasar. 